Bryant University

Bryant Digital Repository

Marketing Department Journal Articles

Marketing Faculty Publications and Research

2015

\title{
Federal Bid Protests: Is the Tail Wagging the Dog?
}

Michael J. Gravier

Bryant University, mgravier@bryant.edu

Timothy G. Hawkins

Western Kentucky University, timothy.hawkins@wku.edu

E. Cory Yoder

Naval Postgraduate School, ecyoder@nps.edu

Follow this and additional works at: https://digitalcommons.bryant.edu/mark_jou

Part of the Labor Relations Commons, and the Other Business Commons

\section{Recommended Citation}

Gravier, Michael J.; Hawkins, Timothy G.; and Yoder, E. Cory, "Federal Bid Protests: Is the Tail Wagging the Dog?" (2015). Marketing Department Journal Articles. Paper 67.

https://digitalcommons.bryant.edu/mark_jou/67

This Article is brought to you for free and open access by the Marketing Faculty Publications and Research at Bryant Digital Repository. It has been accepted for inclusion in Marketing Department Journal Articles by an authorized administrator of Bryant Digital Repository. For more information, please contact dcommons@bryant.edu. 
FEDERAL BID PROTESTS: IS THE TAIL WAGGING THE DOG?

*Timothy G. Hawkins, Ph.D.
Assistant Professor
Western Kentucky University
Department of Marketing
1906 College Heights Blvd \#21059
Bowling Green, KY 42101-1059
Phone (270) 745-2412
Email: timothy.hawkins@wku.edu

\author{
E. Cory Yoder \\ Senior Lecturer \\ Naval Postgraduate School \\ Graduate School of Business and Public Policy \\ 555 Dyer Rd \\ Monterey, CA 93943 \\ Phone (831) 656-3619 \\ Email: ecyoder@nps.edu
}

And

Michael J. Gravier, Ph.D., C.T.L.

Associate Professor of Marketing and Global Supply Chain Management Bryant University

1150 Douglas Pike

Smithfield, RI 02917

Phone (401) 232-6950

Email: mgravier@bryant.edu

2015

* Corresponding Author 
FEDERAL BID PROTESTS: IS THE TAIL WAGGING THE DOG?

ABSTRACT. The fear of receiving a bid protest is said to affect acquisition strategies, yet it has not been empirically explored. Based on the Public Value Framework and interviews with contracting personnel, this research tests a model of antecedents to and consequences of the fear of a protest. Survey data was obtained from a sample of 350 contracting personnel. The fear of protest is mitigated by having sufficient procurement lead time and by source selection experience, and increased by protest risk. Fear of protest increases compromised technical evaluations, added procurement lead time, and transaction costs, while it decreases contracting officer authority and is associated with source selection method inappropriateness. Compromised technical evaluations, in turn, decrease contractor performance while contracting officer authority increases contractor performance. Thus, findings suggests that, indeed, the tail is wagging the dog. The research concludes with several managerial implications, study limitations and future research directions.

Keywords: Bid Protest; Federal Contracting; Acquisition Strategy; Source Selection 


\section{ABOUT AUTHORS.}

Timothy G. Hawkins, Lt Col (ret), USAF, Ph.D., CPCM, C.P.M., is an Assistant Professor in the Department of Marketing at Western Kentucky University. Dr. Hawkins has published articles on procurement and logistics topics in scholarly publications such as: the Journal of Contract Management, Journal of Business Logistics, Journal of Supply Chain Management, Journal of Business Research, Journal of Purchasing and Supply Management, International Journal of Logistics Management, Industrial Marketing Management, Journal of Business Ethics, Supply Chain Management: An International Journal, the Journal of Marketing Channels, Air Force Journal of Logistics, and the Journal of Public Procurement. His current research interests include performance-based logistics, electronic reverse auctions, procurement ethics, buyer-supplier relationships, strategic sourcing, services procurement, and supplier performance management. Prior to his academic career, Dr. Hawkins worked in Global Procurement for NCR Corporation and served as a warranted contracting officer for the U.S. Air Force.

E. Cory Yoder CDR E. Cory Yoder, USN (Ret.), is a senior lecturer and academic associate at the Naval Postgraduate School. He holds an MA in National Security and Strategic Studies (Naval War College); an MS in Management (Naval Postgraduate School); a BS in Business Management (Indiana University); and Business Resource Management certificate (University of Virginia - Darden), and is a Beta Gamma Sigma honor society member and RADM John J. Schieffelin awardee. He has published in, but not limited to, the Journal of Public Procurement, Army AL\&T, NATO Proceedings, and Defense Acquisition Review Journal. His current research interests include strategic contract planning for operations, humanitarian and disaster contract response, performance and compliance auditing for contracting organizations, and creating business efficiencies through sound contracting and business disciplines.

Michael J. Gravier, Ph.D., C.T.L., is Associate Professor of Marketing and Global Supply Chain Management at Bryant University. Dr. Gravier has published articles on the factors affecting supply chain strategies and relationships such as transportation, ethics, procurement practices, and technological obsolescence. He has also published and presented on logistics and supply chain pedagogy. His research has appeared in International Journal of Logistics Management, Supply Chain Management: An International Journal, and Journal of High Technology Management Research, and Journal of Business Ethics. 


\section{FEDERAL BID PROTESTS: IS THE TAIL WAGGING THE DOG? INTRODUCTION}

A central tenet of a public contracting system is to maintain the public's trust via instilled integrity, fairness, and openness. A bid protest is a corrective mechanism to ensure integrity and fairness by providing an interested party with a process to air complaints and obtain relief (Manuel \& Schwartz, 2011). A protest is a written objection that can occur at any stage of the contract award process (see Table 1). Most commonly, protests result from alleged errors or mistakes committed by the agency. The most common errors cited in protests are: poorly written or vague contract requirements, failure to follow the process or criteria laid out in the request for proposals, and failure to adequately document findings (GAO, 2014; Rumbaugh, 2010).

\section{TABLE 1}

\section{Federal Acquisition Regulation (FAR 33.101) Definition of a Protest}

"Protest" means a written objection by an interested party to any of the following:

(1) a solicitation or other request by an agency for offers for a contract for the procurement of property or services,

(2) the cancellation of the solicitation or other request,

(3) an award or proposed award of the contract, or

(4) a termination or cancellation of an award of the contract, if the written objection contains an allegation that the termination or cancellation is based in whole or in part on improprieties concerning the award of the contract.

Increasingly, protests are being filed for business reasons rather than to correct mistakes or errors. Between 2009 and 2013, protests grew from 1,989 to 2,429—a 22\% increase during a period of increased federal austerity. When measured against the number of opportunities to protest from 2011 to 2013, the number of protests increased 29\% (from $0.014 \%$ to $0.019 \%$ of contract actions, including delivery orders). The 
protests have also increased their disruptive power. Of those protest cases that made it to a decision in 2013 (i.e., the few that were not dismissed, settled, or withdrawn), $17 \%$ were sustained, and $43 \%$ of all protest cases were effective (either sustained or resulted in corrective action by the agency prior to decision). Evidence from one military department reveals that bid protest effectiveness increased from $37.9 \%$ in 2005 to $43.9 \%$ in 2010; more disturbingly, when controlling for the number of protestable contract actions, the rate for effective protests went from 0.65 to 1.59 per 1,000 actions, a 144\% increase (FPDS-NG). Acquisition officials loathe the receipt of a bid protest. The potential to receive a bid protest drives agencies to incur costs to: (1) prevent a protest (e.g., thoroughly documenting and substantiating proposal evaluations and trade-off decisions), (2) to defend against an actual protest lodged, and (3) to take corrective actions. At best, an agency's voluntary corrective action means the competition is reopened, and proposals are allowed to be revised necessitating further evaluations and delaying the contract award. At worst, an authority such as the Government Accountability Office sustains the protest meaning that the procurement process must often start anew. This adds even more time and delays receipt of needed goods and services resulting in significant rework. The end users bear costs as well, since their requirements are delayed or go unfulfilled. Hereinafter, we refer to the severely negative attitude toward receiving a bid protest as a "fear of protest."

Evidence suggests that agencies sometimes change their acquisition strategies due to fear of protests. For example, fear of a protest could prompt officials to try to structure a procurement in a manner they deem less likely to be protested, such as using lowestprice, technically-acceptable (LPTA) source selection method instead of 
a full tradeoff method (Schwartz et al., 2013). Other reactions include awarding more contracts than intended to avoid a protest (e.g., Littoral Combat Ship).

While scholars and the GAO have identified these deleterious effects of bid protests on the government (Gordon, 2013), no research to date has quantified them. Specifically, we do not know the magnitude of fear of protests. Neither do we know the extent and manner that fear of a protest affects acquisition strategies or the lengths that acquisition professionals will go to avoid a protest. The purpose of this research, therefore, is to quantify the magnitude of protest fear, and to explore the antecedents and consequences of protest fear.

The remainder of this research is organized as follows. First, we present a background on bid protests. Second, the study discusses the conceptual framework and proposed hypotheses. The Public Value Framework is consulted to illuminate the relevant antecedents and consequences (Figure 1). Next, the study presents the research design and methodology. Then the study provides an analysis of the proposed models and reports the findings. Lastly, the study offers a summary discussion, including conclusions and implications.

\section{Background on Bid Protests}

The evidence that bid protests are a problem comes from multiple vectors. Firstly, as already mentioned, the number and effectiveness of protests are increasing, especially since the economic downturn. Protests traditionally result from alleged errors or mistakes such as poorly written or vague contract requirements, or failure to follow the process or criteria laid out in the request for proposals, or lack of sufficient documentation (GAO, 2014; Rumbaugh, 2010). Other 
traditional causes of protests include: a lack of meaningful discussions, defective solicitations, improper exclusion from the competitive range, a lack of cost realism, and agency bias or bad faith (GAO, 2014;

Rumbaugh, 2010).

The increase in business motivations to file a bid protest derives from multiple factors. When agencies do not adequately document or debrief losing bidders, the losing companies may file a protest to determine why they lost the competition. Losing bidders may try to demonstrate their commitment to stakeholders and executives, even setting the precedent for the competition that they will delay contract award rather than acquiesce quietly (Schwartz, Manuel, \& Martinez, 2013). Sometimes protests are filed by incumbents to delay a switch in contractors, thereby gaining a few more months of revenue.

Bid protests levy monetary and non-monetary costs. Protests may result in: (1) a stop-work order that suspends performance (i.e., a delay to the agency), (2) reevaluating proposals (i.e., a second chance), (3) paying proposal preparation costs and protest filing costs to the protester (i.e., lost agency funds), (4) terminating an awarded contract(s) and re-soliciting the project (i.e., a delay to the agency and a second chance to the protestor) (Rumbaugh, 2010), and/or (5) a settlement that entails more awards than the agency anticipated to appease the protestor or a significant subcontract award from the successful prime contractor (Hoffman, 2013).

Fear of bid protests also increases transaction costs. Often, a fear of a bid protest will result in awarding more contracts than would have been awarded if there was no fear of a bid protest. In certain multiple-award contracts there is a minimum dollar value that the government is obligated to pay as consideration. This results in 
increased spending of taxpayer money that could have been more efficiently spent by awarding to fewer, more competitive contractors. For example, the DODIG (2009) found that under the Seaport-E program, the Navy awarded 1,279 contracts for professional services yet 975 (75.6\%) never received a task order. Each of these contracts required either a $\$ 10,000$ or $\$ 2,500$ minimum obligation. In addition to added funds, added contracts create extra work for the contracting officer to administer, duplicate inventory, can increase transportation costs, result in non-optimal use of taxpayer money, and often upset contractors who never get an award under a multiple award contract for which they believed they were competitive. Although a reduced risk of a protest is accomplished, ultimately less value is added by the contracting process. What this does not accomplish is a best option for the customer or the taxpayer, nor does it provide fairness to the stronger contractors.

One way that the Department of Defense (DoD) acquisition workforce avoids protest is to placate potential protesters. For example, building, fielding, and sustaining two varieties of Littoral Combat Ship platforms substantially increased costs relative to doing so for a single platform (O'Rourke, 2014). Another method to avoid bid protests relies on choosing sub-optimal source selection processes, such as minimizing discussions or even employing an LPTA source selection process when a full tradeoff method is more appropriate (Gordon, 2013). For example, the Air Force seriously considered an LPTA method for its controversyridden aerial tanker acquisition (Pocock, 2009), currently running a $\$ 1.5$ billion cost overrun (Gates, 2014).

Another tactic to diminish bid protest risk consists of engaging in multiple rounds of discussions that essentially level the playing field of competitors rather than providing clearer evaluation criteria up-front. This 
tactic frequently results in retaining mediocre suppliers in the consideration set, increasing the likelihood for a sub-optimal or mediocre contractor to provide important outsourced services/goods to the government. Clearer evaluation criteria better distinguish amongst firms, diminishing the propensity to retain mediocre firms in the competitive set.

An agency's best policy to prevent a protest is to mitigate the causes of the protest; the greater the fear of protest, the more likely the agency will focus on mitigating the causes of the protest. The desire to avoid a protest is the driving force behind acquisition decisions, internal and external policies, and resources applied to mitigate the threat of a protest (Gordon, 2013; Kendall, 2012; Knauth, 2013; Manuel \&

Schwartz, 2011; Schwartz et al., 2013; Maser \& Thompson, 2010;

O'Rourke, 2014). Next we develop the theoretical framework and hypothesis for the antecedents and consequences of the fear of protests.

\section{LITERATURE REVIEW \& HYPOTHESES}

\section{Public Value Framework (PVF)}

In the private sector, industry often uses shareholder value as a means of evaluating itself. In contrast to private sector operations, the government's strategy does not revolve around a specific bottom line such as shareholder wealth. Contracting professionals must satisfy multiple stakeholders such as regulatory requirements (e.g., the FAR), internal customers, the private sector, and the taxpaying public. PVF was introduced by Harvard professor Mark $\mathrm{H}$. Moore and has been used to evaluate and identify value in the public sector. The PVF has been utilized to motivate public managers to reconsider what is valuable in their services, and to rethink the management and effectiveness of their services (Coats \& Passmore, 2008). 
The PVF can be explained by the strategic triangle (Heymann, 1987; Moore, 1995): value, the authorizing environment, and resources. Value determines how the organization measures its performance. The purpose of the organization derives from the vision inspired by the value proposition it provides to the public, usually called public value. The organization justifies its existence to stakeholders-internal and external-based on the vision inspired by its definition of public value (Moore, 2000). In essence, value in a governmental organization equates to mission. Contracting officers demonstrate value by measuring performance related to and resulting from their ability to connect capable suppliers to internal organizations in need of quality goods and services.

The authorizing environment for the organization includes citizens, elected representatives, interest groups, and the media that comprise the wellspring of legitimacy and support (Moore, 2000). Legitimacy and support-tangible and intangible-define the enterprising leader's terrain of influence for pursuing public value, and is limited by the stakeholders and institutions that provide the necessary financial resources and consent. In turn, the resources define the operational capability of the organization. Operational capability determines organizational performance, which depends on sufficient know-how and capability to attain the defined public value. Operational capability may reside entirely within the organization, although in the case of contracted services and goods, it frequently exists outside the organization. Organizations increasingly leverage supplier relationships to achieve desired results, which increases the strategic value of the contracting officer.

PVF observes that in the private sector, organizational survival and financial performance align well with the social value of the 
organization. A retailer that efficiently and effectively provides needed goods to consumers will survive and be profitable. Non-profits exist to provide needed social value where the private sector cannot be profitable and sustain itself. For the non-profit manager, benefits accrue as the result of satisfying stakeholders in the authorizing environment, ideally through demonstrated delivery of public value. However, different members of the authorizing environment often have differing priorities when it comes to public value and how to achieve it.

Contracting professionals add value by helping to meet the operational needs of the government and, at the same time, providing fairness and addressing the various public policy issues required by law and regulation. When these align, customers receive what they require at a fair and reasonable price, and this satisfies the requirements of governing policies.

Contracting officers sometimes take steps throughout the acquisition process to avoid a protest. With regard to the fear of protest, high dollar contracts in particular hold great interest to media and elected officials; there may be an element of public shame if a source selection is protested. If there is a notion that organizational management would not support the contracting officers and that the protest may reflect poorly on them in the media or political arena, there can be a tendency to take measures that can sub-optimize source selection decisions and outcomes in order to avoid a protest. With these concerns in the back of a contracting officer's mind, the contracting officer may, for example, minimize discussions or even employ an LPTA source selection process when a full tradeoff method is more appropriate (Gordon, 2013). When this occurs, the contracting system is not optimizing public value. 
Fear of a protest is a pragmatic concern for contracting professionals. Significant time is consumed addressing a protest. Ultimately, contracting officers then have less time and resources to devote to other duties; the needs of the customer do not stop because of a protest. This decreases the value of the contracting support.

\section{Antecedents to Fear of Protest}

\section{Sufficiency of Planned Procurement Administrative Lead Time}

For buyers, time has become the ultimate non-fungible resource, with important implications for the sourcing and supplier relationship processes. One major retailer's buyers meet only one hour per quarter with suppliers (Hansen, 2009). Indeed, the relationship management strategy reduces essentially to the time management strategy designated during the source selection process.

Sufficient planned procurement administrative lead time (PALT) represents the extent to which adequate time is allotted to accomplish a source selection. Insufficient PALT is often the result of funding constraints that occur toward the end of the fiscal year. Expedited requirements and poor planning are also common reasons that can lead to insufficient PALT. Protestable errors are more likely to occur when sufficient lead time is not allocated (Hawkins et al., 2011) to: properly define requirements, evaluation criteria, and instructions to offerors; train the technical evaluators; evaluate proposals; document evaluations and tradeoffs; and prepare for and brief decision makers. The acquisition team's capability to perform a source selection successfully depends on sufficient time to prepare.

In terms of PVF, time affords the ability for acquisition teams to apply their knowledge and skills, bolstering operational capability. 
Acquisition professionals also need time to communicate with stakeholders to garner support and communicate potential impacts to the value proposition. Insufficient time constrains operational capability, support from the authorizing environment, and evaluation of impacts on public value. Therefore, it is posited that:

H1: Insufficient planned PALT is positively related to fear of protest.

\section{Contracting Officer Experience}

The PVF holds that operational capability is the measure of how government activities deliver value. Operational capability represents requisite knowledge, skills, and abilities-all of which depend on experience. Buyer experience has been found to affect government procurement processes (Hawkins and Muir, 2014). The more experience a contracting officer has, the less concern of a protest there should be since the individual has acquired more knowledge in techniques and practices to prevent bid protests and prevail in the event of a protest.

Experience reflects the sum total of the contracting officer's knowledge, skills, and abilities that result from experience at source selection decisions. In the PVF, organizational goals derive from its definition of public value, and contracting officer experience represents a primary source of operational capability for performance at achieving value. Econom (2006) argued that federal agencies must consider contract management as a core competency because the functions performed by third-party contractors are often essential in successfully achieving organizational goals. She concluded that the success of acquisition organizations is largely dependent on hiring personnel who possess the right mix of skills, abilities, experience, and training. Practitioner survey work reveals that a small percentage $(\sim 5 \%)$ of 
acquisition leaders rates the workforce as highly competent, indicating that competence is a scarce resource (Clark, 2015).

Other studies have also found that this right mix is critical to achieving contract performance outcomes (United States Merit Systems Protection Board, 2005). Time spent in a competency correlates strongly with self-reported proficiency levels in that competency (FAI, 2012), suggesting that experience matters. In terms of public value, greater contracting officer experience improves operational capability through enhanced understanding and expertise with the authorizing environment. Therefore, it is hypothesized that:

H2: The greater contracting officer experience, the lower the fear of protest.

\section{Consequences of Fear of Protest}

\section{Compromised Technical Evaluation}

Evaluation factors and significant sub factors must (1) represent the key areas of importance and emphasis to be considered in the source selection decision; and (2) support meaningful comparison and discrimination between and among competing proposals (FAR 15.304(b)). Agencies must evaluate the proposals and assess their relative qualities based only on the factors and subfactors specified in the request for proposal (RFP) (Rumbaugh, 2010). Deviations from the strict language defining the meaning of factors and subfactors can invite protests. Technical evaluators often do not understand or appreciate this constraint. In terms of PVF, poorly-trained or technical evaluators unknowledgeable in source selections inhibit the agency's operational capability.

Commonly, the evaluators assessing proposals are not the same individuals who defined the meaning of the factors and subfactors. Thus, technical evaluators can bring their own interpretation or agenda to bear 
on their evaluations based upon their relationship to different components of the authorizing environment that provides legitimacy and support. For these reasons, the contracting officer, legal advisor, and contracts committee advisors often require numerous, meticulous changes to precise wording of evaluations. Evaluators are constrained on what they can say in the evaluation - even though the point otherwise intended may make a meaningful distinction between offers. Additionally, definitions of the factors or subfactors may not account for meaningful distinctions. Often this phenomenon reflects a lack of foresight sometimes preventable, sometimes not. Sometimes the distinction is only illuminated upon evaluation of proposals. At this point, the source selection team must weigh a delay in the schedule against the benefit of changing the definition of factors or subfactors to account for the meaningful distinction, and allow offerors time to revise their proposals. Often, however, the customer is not willing to delay the source selection, and the subfactors are not revised. As described by PVF, the disconnect between profit and social good pushes contracting officers toward managing a leg of the strategic triangle under their influence; by compromising technical evaluations (operational capability), they elevate performance measures presented to their authorizing environment, which diminishes the fear of protest. Therefore, it is posited that:

H3: Fear of protest is positively related to compromised technical evaluations.

\section{Source Selection Method Appropriateness}

The acquisition's authorizing environment for competitive formal source selections allows several methods: lowest-price, technicallyacceptable (LPTA), price-performance tradeoff (PPT), or a full tradeoff. In PVF logic, each method defines how to measure the public value of the contract. According to FAR 15.101-2, the LPTA source selection 
process is appropriate when best value is expected to result from selection of the technically-acceptable proposal with the lowest evaluated price. There are many reasons why a contracting officer might opt for the LPTA. One major benefit of this strategy is that the agency can greatly shorten the evaluation process because once the low price proposal has been found to be technically acceptable, there is no need to evaluate the acceptability of any other proposals (Cibinic et al., 2011, p. 680).

The source selection method appropriateness depends on the requirement and the buying situation. Generally, the greater the performance risk, criticality of the requirement's successful delivery to the agency's mission, dollar value, environmental dynamism, uncertain requirements, and complexity, the more important contractor performance becomes and the less critical cost/price become. In these cases, an agency may decide that the best-value offer is determined by a full tradeoff of price and non-price factors. A full tradeoff process is appropriate when it may be in the best interest of the government to consider an award to a company other than the lowest-priced offeror or other than the highest technically-rated offeror (FAR 15.101-1).

In practice, however, agencies may not select the source selection method that is best suited to the requirement and the buying situation. Indeed, a practitioner survey indicates that only $5 \%$ of acquisition leaders rated the workforce highly competent at selecting the right contract structures, techniques and strategies (Clark, 2015). Today's budget-constrained environment may influence managers to prefer LPTA over a full tradeoff. Managers may also wish to avoid a protest, in which case the LPTA method is clearly the lower-risk alternative. Air Force acquisition leaders, following several bid protests 
and failed attempts to acquire a new tanker aircraft, seriously considered an LPTA method for a multi-billion dollar weapon system (Pocock, 2009). Finally, quite often managers prioritize the contract award date (i.e., PALT) over due diligence in contractor selection (Hawkins, 2012). These factors implicate overuse of LPTA because it is simpler and faster, with lower risk of making a protestable mistake. In all these scenarios, public value and organizational performance suffer in the eyes of the authorizing environment, and contracting officers resort to changing the definition of performance to reduce the perceived threat to public value performance. Therefore, we posit that:

H4: Fear of protest is negatively related to source selection method appropriateness.

\section{Added PALT}

Naturally, as the concern over a protest grows, acquisition teams take added measures to prevent them. In PVF terms, concerns over a protest embody threats to legitimacy and support. Added measures reflect acquisition team efforts to leverage operational capability to bolster public value performance in response to the threats. Added measures often manifest as increased reviews resulting in increased iterations of source selection documents such as source selection plans, requests for proposals, technical evaluations, small business strategy, comparative analyses, briefing charts, source selection decision documents, and evaluation notices to offerors - just to name a few. These revisions consume time during the source selection. Additionally, a conservative stance may result in added rounds of discussions to clear up all proposal deficiencies and weaknesses - a concept referred to as technical leveling. Conservatism may also result in retaining otherwise non-competitive offerors in the competitive range adding time to 
negotiate with and evaluate another offer. Theoretically, acquisition managers have limited influence over the authorizing environment (legislation), but they do have influence over PALT, an important operational capability that may improve performance. Therefore, it is hypothesized that:

H5: There is a direct positive relationship between fear of protest and the added PALT.

\section{Contracting Officer Perceived Authority}

Contracting officers uniquely hold authority to enter into, administer, and terminate contracts. They are the only individuals authorized by law to bind the U.S. Government. Contracting officers are responsible for: (1) ensuring that all the necessary actions for effective contracting are accomplished, (2) ensuring compliance with the terms of the contract, and (3) safeguarding the interests of the U.S. Government in its contractual relationships. In terms of PVF, the contracting officer's authority provides the operational capability to protect the various stakeholders' interests (e.g., taxpayer, contractor, Government, internal customers). In this capacity, the contracting officer reinforces legitimacy and support in the pursuit of greater public value.

While contracting officers must request and consider the advice of specialists (e.g., law, engineering, finance, etc.), ultimately, decisions within their purview are their responsibility (FAR 1.602-2). Upon receipt of a protest, legal counsel must divert time and effort to defend the agency's actions. Thus, legal counsel reviews the many iterations of the multitude of source selection documents to ensure legal sufficiency, compliance to regulations and policies, and to mitigate the risks of protests. With the consequences at stake, such as setting precedent, reputation, and invested time, legal counsel is typically conservative in attempting to prevent a bid protest. Since legal counsel brings their own 
unique legal authority and professional expertise, contracting officers and acquisition managers rely heavily on its opinions and recommendations. Contracting officers are likely to yield their decision making discretion (e.g., removing an offeror from the competitive range) when legal counsel disagrees with them. During the scale development process for this study, one interviewee shared: "We almost never move forward unless they [legal] give us their okay. It would be very, very hard-very challenging." This comment alludes to the influence of legal counsel on acquisition and unit leaders; in its advisory role, it subtly, yet strongly, affects the contracting officer's authority through its opinions and recommendations.

Other parties impose a similar sway on contracting officers' decision authority. For example, higher ranking contracts committee members and leaders may also hold opinions on a particular source selection matter that are contrary to that of the contracting officer. In such cases, contracting officers may perceive unwritten career implications to making contrarian decisions. Thus, although certain statutory authority resides with the contracting officer, the reality is that such authority is yielded in practice. As protest risk - and thus, fear of a protest - grows, so does the involvement of legal counsel, other reviewing parties, and acquisition leaders. Increased involvement likely reduces the contracting officer's perception of decision latitude. In some instances, contracting officers indicate that legal counsel would not allow them to make decisions - creating the organizational norm that legal has the final decision, not the contracting officer. As posited by PVF's strategic triangle-and as intended by law-the operational capability of the contracting officer depends on the legitimacy and support from the 
legal and other oversight in the authorizing environment. Thus, we posit that:

H6: There is a negative relationship between fear of protest and the contracting officer's perceived authority.

When an individual holds decision-making authority coupled with accountability for the results of decisions (e.g., a contracting officer), he or she tends not to defer decisions entirely to others. This is not to say, however, that others are not consulted. In public contracting, similar to input from advisors on source selection method choices, advisors review all of the written technical evaluations with respect to the evaluation criteria published in the request for proposals. They screen for errors, omissions, consistency, and other matters of compliance with laws, regulations, and policies in an effort to mitigate the odds of receiving a bid protest. In doing so, they are aligning the legitimacy and support with their other resources in order to bolster public value outcomes. Advisors often limit what the technical evaluators can say. Such scrutiny can make difficult the ability to meaningfully discriminate between proposals. Similar to the previously-discussed rationale, while contracting officers also review the technical evaluations for errors, they are more apt to accept more risk. Thus, it is posited that:

H7: Contracting officer authority is negatively related to compromised technical evaluations.

\section{Transaction Costs}

The substantial increase in protests by industry against competitive sourcing decisions have increased legal and acquisition requirements, caused program delays, and delayed delivery (Young, 2007)—all of which increase transaction costs. Transaction costs reflect the monetary costs of resources devoted to executing a formal source 
selection - largely comprised of labor costs of the different acquisition professionals involved such as the contracting officer, contracting specialist, technical evaluator, legal counsel, cost/price analyst, past performance team, program manager, Small Business Administration representative, and consultants. Transaction costs could be considered an opportunity cost of resources not devoted to other work requirements (e.g., contract and program administration).

An increased risk of protest provokes risk mitigation in the form of increased operational capability; in other words, more personnel are involved and they allocate more of their time and effort to defending against a potential bid protest. Thus,

H8: There is a direct positive relationship between fear of protest and transaction costs.

\section{Contractor Performance}

An organization's mission is increasingly performed or supported via outsourced contracts, which means that contractor success has become a strategic component of operational capability for the agency it supports. In order for an agency to provide its public value, the supplier must perform well under the obligations of their contract. The development of contract obligations during the source selection process determines the level of performance ultimately received.

When the Government utilizes a best-value source selection method, technical evaluators apply evaluation factors and subfactors to proposals to determine the best-value offer. This process helps the government to hedge against substandard and/or non-performance by weeding out the less-capable firms (or teams of firms). The premise of source selection is that by applying the evaluation factors and subfactors, a very capable contractor has higher odds of being deemed 
the best-value offer. Nonetheless, the Government struggles in its efforts to unambiguously define technical factors and subfactors such that they can make meaningful distinctions between offers (Rumbaugh, 2010). Once weaknesses in evaluation factors are realized, particularly after receipt of proposals, acquisition teams are reluctant to fix the factors by amending the RFP and inviting revised proposals since this delays the acquisition milestones. Additionally, conservative evaluators (and their advisors), for fear of protest, often engage in multiple rounds of discussions that essentially level the playing field of competitors, and often they retain mediocre offerors in the competitive range for fear of receiving a bid protest. Had the evaluation criteria been better able to distinguish amongst the firms, the propensity to retain mediocre firms within the competitive range would be diminished. In essence, the legitimacy provided by the authorizing environment is redirected to undermine the contracting agency's operational capability for technical evaluation, which diminishes the third leg of the PVF strategic triangle: performance. Together, therefore, it is expected that:

H9: There is a negative relationship between compromised technical evaluation and contractor performance.

Contracting officers are generally more cognizant of and empathetic to the effects of contractor performance on the requiring organization's mission attainment than are risk-averse advisors such as legal counsel. Contracting officers may prioritize mission performance over protest risk in making key decisions during a source selection. For example, they may be more apt to remove a less-competitive or lesscapable offeror from the competitive range, assign a lower proposal rating, and not engage in added rounds of discussions solely to mitigate protest risk (thereby mitigating technical leveling). In some cases, 
contracting officers may also be more apt to choose a full tradeoff rather than a LPTA source selection method as the most appropriate means to attain the best-value contractor. The full tradeoff method allows the Government the flexibility to pay more for superior capability and/or past performance when warranted. Since the procedures are so nuanced, full tradeoff also requires more effort, invites more error, and thus, protest risk. These actions reduce the odds of having to award a contract to a less-capable contractor, for example, in the case of a LPTA source selection method. In effect, proper alignment of legitimacy and support with contracting operational capability bolsters public value outcomes. Therefore, it is hypothesized that:

H10: There is a positive relationship between source selection method appropriateness and contractor performance.

Taken together, then, it is expected that a contracting officer with decision-making authority - and who does not defer that authority to others - will make decisions that accept more risk yet does not impede the selection of the best-suited contractor for the task at hand. When the selection is not constrained by procedures, greater decision latitude results in a better match between the offeror's capabilities and the contractual requirements. This reflects better alignment between the legs of PVF's strategic triangle: the authorizing environment bolsters the contracting officer's capability to align the offeror's capabilities with the desired public value outcomes. Examining the troubled U.S. defense acquisition system's capability to reinforce contracting officer authority, the Defense Business Board concluded: "Of the eight findings, three of them concern the acquisition workforce, a large group of dedicated public servants who work diligently, but ultimately struggle within a broken system that is focused on avoiding mistakes rather than 
producing more, in less time, at less cost" (Punaro, 2012). The contracting officer achieves contract success in proportion to the authorization and support from the acquisition authorizing environment. Therefore, it is posited that:

H11: There is a positive relationship between contracting officer authority and contractor performance.

The relationships posited above are visually depicted in Figure 1. Fear of protest can also be affected by the criticality of the requirement and by protest risk. Therefore, these constructs are shown as control variables.

Figure 1

\section{Conceptual Model of Fear of Protest}

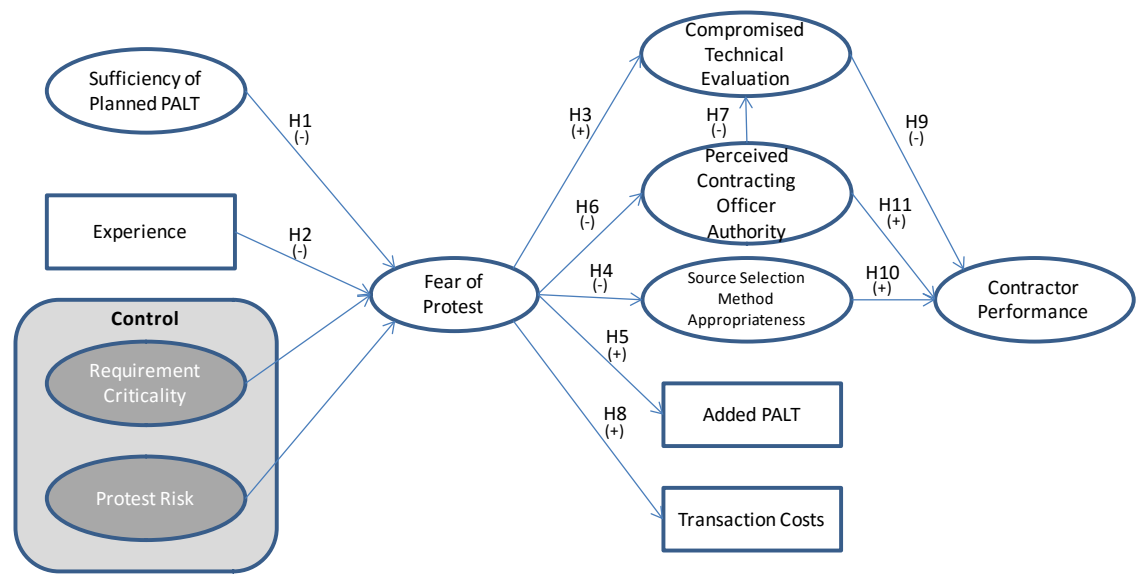

\section{METHODOLOGY}

This study employed a survey to collect empirical data followed by quantitative analysis. The research employed structural equation models using the cross-sectional survey data. The remainder of this section details the survey development, pretest, the sample, data collection, and reliability and validity.

\section{Questionnaire Design and Construct Measurement}


All scales measuring latent constructs used a Likert-type scale. No previously-validated scales were available to measure the fear of protest, contracting officer authority, and source selection method appropriateness; thus, interview data (Appendix A) were used to develop these scale items (Appendix B). Fear of protest describes the level of apprehension a contracting professional has about receiving a bid protest. The contracting officer authority construct described how empowered the contracting officer is to make final decisions during the source selection process. Source selection method appropriateness is the perceived extent that the chosen source selection method fits the requirement, the goals of the source selection, the commercial market, and the acquisition situation.

Pre-existing scales were used when available. A three-question scale was used to measure the sufficiency of planned PALT in the milestones and allocated by the acquisition team and its managers to conduct the source selection (Hawkins and Muir, 2014). Compromised technical evaluation assessed the extent to which technical evaluators complained about the limitations imposed on the wording of their written technical evaluations. Contractor performance is a measure of the contractor's performance levels and the degree to which requirements were satisfied. The scale was adapted from Fawcett, Smith, \& Cooper (1997), Cannon, Achrol, \& Gundlach (2000), and Prahinski \& Benton (2004).

The remaining variables were objectively measured. Experience was measured as the number of source selections the respondent previously experienced. This could include FAR Part 15 (i.e., formal) and non-FAR Part 15 (e.g., simplified) source selections. It could also include those source selections to which the respondent served as the procuring 
contracting officer as well as those to which the respondent served as an advisor, reviewer, or specialist. Added PALT objectively measured the difference between the planned PALT (in days) and the actual PALT (in days). Transaction costs attempted to quantify the personnel costs based on amount of time spent on the source selection by each member of the team. Transaction costs were calculated by asking respondents the number of people by role, pay grade, and fraction of one year's time spent on the source selection. The average 2013 General Schedule annual pay was used to calculate the cost for each role, and then summed for each source selection.

\section{Survey Pretest}

Six industry practitioners and academicians tested the initial survey to ensure face validity, construct validity, to construct and validate a conceptual model, and to help develop survey items to validly measure the constructs - many of which were new (i.e., measurement scales did not exist). Additionally, 18 contracting officers were interviewed (Appendix A). Feedback received was used to refine questions and limit

survey length. As a result, one construct was removed and the order of the survey questions was structured to reduce bias among scale items by mixing questions across constructs with like scales and scale anchors.

\section{Sample}

The population for this study consisted of U.S. civilian and military contracting personnel who had executed a FAR Part 15 formal source selection (i.e., a dollar amount greater than $\$ 150,000$ ). This excluded simplified procurements that are generally less susceptible to bid protests. A list of e-mail addresses was generated using data 
extracted from the Federal Procurement Data System-Next Generation (FPDS-NG) database to encompass all transactions that fit the criteria previously stated.

The unit of analysis for this survey was one source selection event. Since nearly all bid protests stem from a protestable action (e.g., a proposal rating, rating justification, or basis of a tradeoff analysis) associated with a source selection, this is the proper unit of analysis for the study. Respondents were instructed to answer the survey questions using their experience from their most recently-completed FAR Part 15 source selection. The most recent source selection was required to serve as the basis of reference in order to prevent respondents' self-selection bias.

\section{RESULTS}

\section{Data Collection}

An online survey was used to collect the data. In order to maximize the response rate, we utilized Dillman's (2000) "Tailored Design Method" for internet surveys. A survey invitation was sent via email to 3,882 contracting officers who had executed a FAR Part 15based formal source selection. The survey was left active for 42 days, with 3 reminders being sent during that time. There were 661 responses received, which yielded a $17 \%$ response rate. Of the responses received, 311 were deleted due to missing or obviously invalid data, leaving 350 usable responses. The final response rate of usable responses was $9 \%$.

The average respondent had 13.6 years of federal contracting experience. Male respondents accounted for 50.64 percent and female respondents accounted for 49.36 percent. Only $2.29 \%$ of respondents held only a high school diploma or general equivalency diploma, 3.14\% 
held an associate's degree, 38\% held a bachelor's degree, $54 \%$ held a master's degree, and $2.57 \%$ held a doctorate. The average number of protests experienced was 1.96 , and $15.4 \%$ of respondents had experienced a sustained protest.

TABLE 2

Contract Type and Goods/Services Procured

\begin{tabular}{|c|c|c|c|}
\hline Contract Type & $\begin{array}{l}\% \text { of } \\
\text { Total }\end{array}$ & $\begin{array}{l}\text { Supply or } \\
\text { Service } \\
\text { Purchased }\end{array}$ & $\begin{array}{l}\% \text { of } \\
\text { Total }\end{array}$ \\
\hline Fixed Price & $60.00 \%$ & Services & $58.00 \%$ \\
\hline $\begin{array}{l}\text { Cost } \\
\text { Reimbursement }\end{array}$ & $27.14 \%$ & Construction & $16.86 \%$ \\
\hline $\begin{array}{l}\text { Time and } \\
\text { Materials }\end{array}$ & $1.14 \%$ & $\begin{array}{l}\text { Supplies or } \\
\text { Commodities }\end{array}$ & $15.71 \%$ \\
\hline Labor Hours & $0.57 \%$ & $\begin{array}{l}\text { Weapons } \\
\text { System }\end{array}$ & $6.57 \%$ \\
\hline Hybrid & $9.14 \%$ & $\begin{array}{l}\text { Other Capital } \\
\text { Equipment }\end{array}$ & $2.86 \%$ \\
\hline Other & $2.00 \%$ & & \\
\hline
\end{tabular}

\section{Reliability and Validity}

Through iterative scale purification (Churchill, 1979) using exploratory factor analysis with varimax rotation, 39 survey items reduced to 25 across seven latent factors. The reliability of latent constructs was assessed using composite reliabilities (Fornell and Larcker, 1981). These measures, ranging from .80 to .96 (see Table 3), proved to be sufficiently reliable, exceeding the minimum acceptable threshold of .70 (Nunnally, 1978). Construct validity was assessed via confirmatory factor analysis (CFA) in LISREL version 8.8. In the measurement model all loadings were significant at the .05 level, standard errors were not abnormal; no standardized loadings exceeded 1.0, and no negative error variances (Heywood Cases) occurred. The measurement model (CFA) exhibited acceptable fit (Table 5). 
TABLE 3

Correlation Matrix and Composite Reliabilities

\begin{tabular}{|c|c|c|c|c|c|c|c|c|c|c|c|}
\hline & FEAR & PALTP & $R C$ & $E X P$ & PRISK & CTE & PALTA & SSMA & $A U T H$ & PERF & $T C$ \\
\hline FEAR & .90 & & & & & & & & & & \\
\hline PALTP & $-.21^{*}$ & .81 & & & & & & & & & \\
\hline $\mathrm{RC}$ & .10 & -.04 & .86 & & & & & & & & \\
\hline EXP & -.10 & -.09 & .01 & --- & & & & & & & \\
\hline PRISK & $.20^{*}$ & $-.24^{\star}$ & $.14^{*}$ & .00 & --- & & & & & & \\
\hline CTE & $.25^{\star}$ & $-.24^{\star}$ & -.02 & -.04 & $.13^{*}$ & .80 & & & & & \\
\hline PALTA & $.11^{*}$ & -.06 & .03 & .06 & .09 & .01 & --- & & & & \\
\hline SSMA & -.07 & $.28^{*}$ & $.26^{\star}$ & .03 & .01 & $-.22^{\star}$ & -.04 & .92 & & & \\
\hline AUTH & -.09 & $.20^{\star}$ & $.20^{\star}$ & .10 & -.06 & $-.24^{*}$ & -.03 & $.40^{\star}$ & .89 & & \\
\hline PERF & -.06 & .20 & $.20^{\star}$ & .00 & -.06 & $-.24^{*}$ & $-.11^{\star}$ & $.30^{*}$ & $.21^{*}$ & .96 & \\
\hline $\mathrm{TC}$ & $.12^{*}$ & .00 & $.17^{*}$ & $-.13^{\star}$ & .09 & $.13^{*}$ & .06 & -.02 & .04 & -.16 & --- \\
\hline
\end{tabular}

Notes: (1) Correlations are below the diagonal. (2) Composite reliabilities of the latent factors are on the diagonal. (3) *Significant, $p<.05$ (4) FEAR=fear of protest; PALTP=sufficiency of planned procurement lead time; $\mathrm{RC}=$ requirement criticality; $\mathrm{EXP}=$ source selection experience; PRISK=protest risk; $C T E=$ compromised technical evaluation; PALTA=added procurement lead time; SSMA=source selection method appropriateness; AUTH=contracting officer perceived authority; PERF=contractor performance; $\mathrm{TC}=$ transaction costs.

Table 4 shows the average variance extracted (AVE) of each construct; all exceeded the .50 standard, demonstrating convergent validity (Fornell and Larcker, 1981). We then compared each AVE to the variance shared between constructs. None of the shared variances approached the AVE, providing sufficient evidence that the constructs were indeed unique (Lam, Shankar and Murthy, 2004). We tested for non-response bias using Armstrong \& Overton's (1977) approach. Responses were categorized into three groups according to the time received. Tests for differences in three latent constructs and two demographic variables revealed no significant differences, indicating a lack of response bias in the data.

TABLE 4

Convergent and Discriminant Validity 


\begin{tabular}{|c|c|c|c|c|c|c|c|}
\hline & FEAR & PALTP & $R C$ & CTE & SSMA & AUTH & PERF \\
\hline FEAR & .70 & & & & & & \\
\hline PALTP & .04 & .59 & & & & & \\
\hline $\mathrm{RC}$ & .01 & .00 & .68 & & & & \\
\hline CTE & .06 & .06 & .04 & .59 & & & \\
\hline SSMA & .00 & .08 & .07 & .05 & .79 & & \\
\hline AUTH & .01 & .04 & .04 & .06 & .16 & .74 & \\
\hline PERF & .00 & .04 & .04 & .06 & .09 & .04 & .81 \\
\hline
\end{tabular}

Notes: (1) Diagonal entries represent average variance extracted (AVE).

(2) Off-diagonal entries represent shared variance.

TABLE 5

Measurement and Structural Models

\begin{tabular}{cccccccc}
\hline Model & $\begin{array}{c}\chi^{2} \\
\text { (dof) }\end{array}$ & TLI & CFI & AGFI & RMSEA & SRMR & $\begin{array}{c}\text { Critical } \\
\text { N }\end{array}$ \\
\hline Measurement & $\begin{array}{c}396.8 \\
\text { (CFA) }\end{array}$ & .99 & .99 & .90 & .026 & .04 & 326 \\
Full Structural & $\begin{array}{c}534.8 \\
(334),\end{array}$ & .98 & .98 & .88 & .040 & .10 & 261 \\
& $\begin{array}{c}3<.01 \\
p<.0\end{array}$ & & & & & \\
Trimmed & $\begin{array}{c}374.3 \\
(262), \\
p<.01\end{array}$ & .98 & .98 & .91 & .032 & .079 & 298 \\
Structural & & & & & \\
\hline
\end{tabular}

A structural equation model (SEM) was then fit to the data. A global assessment (Bagozzi and Yi, 1988) of the various goodness-of-fit indices indicated questionable fit (Table 5). Most problematic were the AGFI $(<.90)$ and the SRMR (>.08). Examining the hypotheses, the relationship between fear of protest and source selection method appropriateness (SSMA) was not significant. Therefore, we trimmed SSMA from the model. The trimmed model exhibited solid fit (Table 5). While the chi square test was significant, indicating a difference between the hypothesized model and the data, the CFI, TLI, AGFI, RMSEA and SRMR suggest good fit. Table 6 shows the results of hypotheses tested using the trimmed SEM. Nine of eleven hypotheses tested were supported, although the variance explained in the focal endogenous 
respondents; therefore, $\mathrm{H} 8$ was tested outside of the SEM model using regression, and was supported $(F=5.63 ; \beta=.14, \mathrm{t}=2.37, p=.018)$. The values of transaction costs ranged from $\$ 700.08$ to $\$ 3,551,944.33$. The average transaction cost per source selection was $\$ 235,236.34$ (median $=\$ 165,832.55 ;$ std dev $=\$ 291,620.05)$.

\section{Control Variables}

Two control variables were used in order to account for the expected significant effects on fear of protest. Requirement criticality represents the level of significance of a particular acquisition to the unit's mission. This predictor did not significantly affect fear of protest (Table 6). Protest risk consists of two parts since risk is comprised of the sum of the products of the magnitude of the consequences and the probability of occurrence. Questions assessed the desirability of each of five consequences of a protest and each of their associated probabilities of occurring. The five consequences were validated by interview informants to be those most likely to occur and those most abhorred. Risk was calculated by multiplying each consequence's probability of occurrence by the desirability of the consequence. The summed result yielded an overall protest risk score for each survey response, or record. Protest risk consisted of five possible consequences using a Likert-type scale with anchors of completely undesirable and completely desirable, and then listed the same five consequences using a probability of occurrence scale with anchors of $0 \%$ to $100 \%$. Protest risk was a significant predictor of fear of protest (Table 6).

\section{Post Hoc Analysis}

A series of logistic regressions were then run on the perceived appropriateness of two types of source selections-LPTA and full trade- 
off-using respondent rating of appropriateness of the source selection method used. The first step in the test was to include only the respondents that used the particular source selection method (i.e., LPTA or full trade-off). A dummy variable was then created to ascertain how appropriate the respondent thought the use of the method was. The questions used a seven-point Likert-type scale with 1 being "Completely Inappropriate" and 7 being "Completely Appropriate." Respondents that answered the questions with scores of 3 or less were coded as 1, and all others were coded as 0 . Relevantly, 13 out of 133 respondents used LPTA even though they felt it was to some degree inappropriate, and 10 respondents out of 174 used full trade-off even though they felt it was to some degree inappropriate. This totals $7.49 \%$ of the 307 respondents that used either LPTA or trade-off as a source selection method. Both tests used the same binary fear of protest independent variable (Hi/Low) in the aforementioned tests. The logistic regression test to measure the relationship with the use of the Full Trade-off inappropriateness was not significant $(p=.181)$. The test using LPTA inappropriateness was significant $(p=.015)$ with an odds ratio of 4.673 , revealing partial support for H4. A test of the effect of LPTA inappropriateness on contractor performance was significant and negative ( $p=.01$; odds ratio of -4.36$)$, lending partial support to $\mathrm{H} 10$.

We also measured the difference between how many contracts were planned and how many were actually awarded. A binary variable was created in which respondents that saw more contracts awarded than planned were coded as 1 (19 instances; 5.4\%), and all others 0. However, the test of a relationship to fear of protest was not significant $(p=.350)$. 
We asked the 350 respondents how many times they had: (1) awarded a task/delivery order, (2) awarded a sole source contract, and (3) found a way to modify and existing contract, each in order to avoid a protestable competitive procurement. Of the 84 using task orders to avoid a protest, they did this 47 times over their career on average. Of the 67 using sole source, they did this an average of 15 times. And, of the 64 using modifications, they did this 17 times on average.

\section{DISCUSSSION}

The objective of this research was to measure the magnitude of fear of protest and to identify its antecedents and consequences. The evidence provides empirical validation for fear of protest. The PVF was instructive toward these ends, and helped to explain underlying rationales for the effects. The purpose was to better understand the impacts that fear of protests has on acquisition strategy decisions. This is important since acquisition strategy decisions affect the contractor that is selected and the ultimate level of performance that is received. To examine fear of protest, a structural equation model of its antecedents and consequences was tested and found to exhibit good fit to a sample of data from 350 contracting personnel. Many of the findings have significant managerial implications to the effective execution of source selections.

\section{Findings and Implications}

Our evidence reveals that insufficient planned procurement leadtime increases the level of fear of a protest. When acquisition personnel have less time than they believe is necessary to properly conduct the source selection, they perceive greater odds of making a mistake that could be protested. When contracting officers are rushed, contractual 
documents (e.g., statements of work) and pre-award communications (e.g., negotiations) could be compromised which may decrease contractor performance (Hawkins et al., 2011). Shortcuts could preclude the selection of the best contractor or result in selecting a contractor that does not fully understand the requirements. To prevent rushed acquisitions, standard lead times by type of source selection and by complexity of the requirement could be established.

A contracting officer's experience lowered the level of fear of bid protests. Of the 350 survey respondents, the average number of source selections experienced over a career was of 36.7. That is just under 2.8 source selections per year. Note that this seemingly high number of source selections likely includes simplified buys and experience in a variety of roles such as a peer or committee reviewer as well as a contracting officer. Increasing the number of source selections experienced by contracting officers can decrease the fear of protests. There is no equal alternative to on-the-job-training (OJT), but source selection simulations and scenario-based training could be utilized as an alternative and as a supplement to OJT. If the acquisition community is relying solely on OJT, it can take a contracting officer and technical evaluators far too long to gain an adequate level of competence with FAR Part 15 source selections.

Fear of protest appeared to compromise technical evaluations; compromised technical evaluations decreased contractor performance. This construct assessed phenomena such as: (1) technical evaluators not being allowed to say what needs to be said in a technical evaluation, (2) constraints imposed on the evaluations impeding the ability to write a meaningful evaluation, and (3) upon evaluation of proposals, a technical evaluator recognizing a need to change at least one evaluation criterion 
or its definition. Additional training for the technical evaluators could help increase their level of competence within the evaluation process. The evaluation process involves many people that are not necessarily familiar with the case law and pitfalls giving rise to bid protests. Additionally, the technical individuals that determine and define the evaluation criteria should be the same individuals that evaluate proposals (i.e., apply the criteria). Current, detailed, and standardized training for technical evaluators should result in better-defined evaluation criteria and better application of them to proposals.

While fear of protest did not affect perceived source selection method appropriateness, protest fear was associated with the inappropriate use of the LPTA source selection method; in turn, LPTA inappropriateness negatively affected contractor performance. While these effects have been anecdotally espoused by practitioners, this research is the first to quantitatively test the postulates. There were 23 respondents $(7.5 \%)$ that revealed that the source selection method used was to some degree inappropriate. While this proportion appears small, it can be argued that any single instance of an inappropriate source selection method gives room for pause. LPTA could be inappropriately used since: (1) evaluations can generally be accomplished more quickly and easily when evaluated as pass/fail rather than by a subjective rating; (2) the government's recent increased focus on low price; and (3) the lower odds of receiving a bid protest compared to arduous and mistakeprone procedures of a full tradeoff method. Further research should confirm reasons why inappropriate source selection methods are employed, then acquisition leaders should seek ways to mitigate those factors. Perhaps contracting officers should be able to tap an independent panel of contracting professionals when they encounter 
leaders or reviewers who will only approve a source selection method that does not correspond well to the buying situation.

These findings are also germane to contractors. When a buying office develops an acquisition strategy that appears ill-suited to the buying situation (e.g., LPTA versus full tradeoff for a highly complex requirement), it may be due to the fear of a bid protest. However, prospective offerors may misinterpret the use of LPTA as an added emphasis on price. Their bid strategy, then, may be influenced by reducing costs and price, thereby putting high performance at risk, even though the agency may not actually be terribly concerned about price.

The fear of protest diminishes a contracting officer's perceived authority. Diminished contracting officer perceived authority was found to decrease contractor performance directly. Contracting officer's perceived authority also affects contractor performance indirectly by decreasing compromised technical evaluations. Many decisions and source selection documents receive scrutiny via a litany of outside reviews (e.g., supervisors, peer review, contracts committees, legal). Often, legal consel and committee advisors will conservatively require wording changes to documents, changes to ratings, amendments to the request for proposals, impose further discussions to clear up any uncertainty in evaluations, and retain offerors in the competitive range - just to name a few.

This level of oversight is another signal of the importance the government places in avoiding a bid protest. Admittedly, it also coincides with a less competent acquisition workforce (Punaro, 2012). Rather than treating the problem, however, the symptoms gain the attention; fixing the problems of contracting officer competence and a cumbersome source selection processes is difficult and lengthy, while adding oversight 
is quick and simple. The implications are clear: better training is needed for contracting personnel and technical evaluators to develop the requisite competence in source selections, and then oversight and reviews should be curtailed. Ann Rung, the new administrator for the Office of Federal Procurement Policies, recently released an improvement plan identifying acquisition workforce talent development as a key to innovation and performance (Miller, 2014). Some protest risk must be accepted for the sake of efficiency and better decision making (i.e., negotiations and award determination) leading to higher contractor performance.

This research confirmed the presence of outside influence on acquisition strategy decisions, and these influences carry associated implications for contracting. During measurement scale development, one interviewed expert commented, "I will tell you, legal pushes the LPTA. They push it a lot." One survey respondent offered, "At this juncture, there are too many hands in the soup, and the procuring contracting officer (PCO) authority has been diminished. Attorneys need to resume the role of counselors again." Since the source selection method is not a matter of legal sufficiency, attorney influence is curious. Selecting the source selection method is a contracting officer's decision based on experience, knowledge, and professional judgment. Otherwise, Government agencies may employ a costly professional contracting workforce with a high degree of accountability but diminished authority. If not capable, trusted and empowered to make the necessary decisions, procurement clerks (e.g., series 1105) would be much less costly than contracting professionals (e.g., series 1102).

The fear of protest is positively related to an increase in transaction costs. Costs were assessed in terms of the number of 
personnel involved in a sources selection and their allocated time. The average cost per source selection was $\$ 235,236$ (median $=\$ 165,832$ ) with a standard deviation of $\$ 291,620$. Notably, these costs are understated by considering direct salaries only; they exclude the true burdened cost of a government employee. An average of 9 different people worked on a given source selection team in the various roles (an average of 3.5 full-time equivalents). As a percentage of the total contract price, the transaction costs averaged $7.7 \%$ (median 1.2\%). Compared to common interagency surcharges for contracting services (that cover post-award administration costs in addition to sourcing costs) of one-to-eight percent, these pre-award sourcing-only costs seem excessive. Thus, agencies may be operating at costs well above their collected fees, and these costs can be traced to fear of protests.

Post hoc analysis showed that as the fear of protest increases, the number of personnel and the actual procurement lead time increase. From the data, the average planned PALT was 183 days. The average actual PALT was 237 days. The difference, 54 days, constitutes added transaction costs, indicating the degree to which efficiency is compromised by fear of protest. While these salary costs may be dismissed as sunk costs, certainly excess personnel could accomplish other pertinent work if not serving on the source selection team for an extended time. These opportunity costs should not be ignored, particularly given the ubiquitous, persistent failures in other areas of acquisition such as contract administration (DODIG, 2009). Measures that reduce the fear of protest should decrease transaction costs. Likewise, if evaluation, negotiation, internal reviews, and documentation processes can be streamlined, and if agencies can accept more protest 
risk, perhaps lead time can be saved, resulting in reduced transaction costs.

Given the government's budget constraints and highly-leveraged financing, the significant transaction costs associated with source selections should not continue to be ignored. A first step would be to capture the quantified resources required to execute a source selection in a contract action reporting database (e.g., FPDS-NG). Agencies could also follow the for-profit sector's lead by assessing and publishing key metrics such as total spend per sourcing full-time equivalent (CAPS Research, 2011).

These results surrounding transaction costs raise questions concerning the acquisition process in general. For instance, an important criterion for new case law - and hence, new reactive policies and regulations - is fairness, with little regard for efficiency. Is there a ceiling cost on fairness? Is there a point at which fairness is too costly? Additionally, the high transaction costs suggest that the drivers of those costs be considered. Can policies, procedures, laws, case law, and regulations be reexamined and streamlined without compromising fairness? Is government procurement at the point of a source selection overhaul with a keen eye toward efficiency?

\section{Study Limitations \& Future Research Directions}

Limitations of this study, and those common to survey methodologies, should be considered. First, the response rate is remarkably low. However, it is not unlike that of other published business research. Melnyk et al., (2012) revealed a sharp decline in response rates starting in 2002 , with a steady decline of $1 \%$ annually. Five top journals reported low-end survey response rates ranging from $3 \%$ to $8 \%$. Survey length is thought to be one of the key contributors to the decline. 
This survey was necessarily lengthy, and parts of it involved consulting records rather than merely offering attitudes or opinions. Second, because this sample came solely from one military service, the extent of generalizability of the study findings to other government agencies is unknown. Third, the research design relied upon self-reported data from respondents introducing a threat of common method variance (CMV) (Podsakoff \& Organ, 1986). Harman's one-factor test revealed that when all of the items were run in a single factor analysis, the unrotated solution did not result in a single factor, nor did it result in a general factor that accounted for most of the covariation (Podsakoff \& Organ, 1986). Fourth, the perceptual variable LPTA appropriateness was measured with a single item; thus, its reliability could not be determined.

Due to the low amounts of variance in the dependent variables explained by the predictors, other factors that affect the fear of protest, compromised technical evaluations, added procurement lead time, and contracting officer perceived authority should be explored. Future research could also investigate why source selection methods that are perceived to be inappropriate are sometimes used. Finally, future research could replicate this study in civilian U.S. government agencies and in those of other countries. 


\section{REFERENCES}

Armstrong, J. S., \& Overton, T. S. (1977). Estimating nonresponsive bias in mail surveys. Journal of Marketing Research, 14(3), 396-402.

Bagozzi, R. P. \& Yi, Y. (1988). On the evaluation of structural equation models. Academy of Marketing Science, 16(1), 74-94.

Cannon, J. P., \& Perreault, D. (1999). Buyer-seller relationships in business markets. Journal of Marketing Research, 36(4), 439460.

Cannon, J. P., Achrol, R. S., \& Gundlach, G. T. (2000). Contracts, norms, and plural form governance. Journal of the Academy of Marketing Science, 28(2), 180-94.

CAPS Research (2011), "Cross-Industry Report of Standard Benchmarks," Institute for Supply Management and W.P. Carey School of Business at Arizona State University.

Churchill, G.A., Jr. (1979). A Paradigm for developing better measures of marketing constructs. Journal of Marketing Research, 16(February), 64-73.

Cibinic, J., Nash, R. C., \& Yukins, C. R. (2011). Contract administration and personnel. (4th ed.) Formation of government contracts ( pp. 38-82). George Washington University Law School, Government Contracts Program.

Coats, D., \& Passmore, E. (2008). Public value: The next steps in public service reform. London, England: The Work Foundation.

Department of Defense Inspector General (DODIG) (2009). Summary of DoD Office of Inspector General Audits of Acquisition and Contract Administration. Report No. D-2009-071. April 22, 2009.

Dillman, D.A. (2000). Mail and internet durveys: The tailored design method. (2nd Ed.). New York, NY: John Wiley and Sons, Inc.

Econom, S. R. (2006). Confronting the looming crisis in the federal acquisition workforce. Public Contract Law Journal, 35(2), 171219.

Fawcett, S. E., Smith, S. R., \& Cooper, M. B. (1997). Strategic intent, measurement capability, and operation of success: Making the connection. International Journal of Physical Distribution and Logistics Management, 27(7), 410-421.

Federal Acquisition Institute (FAI). (2012, December). 2012 acquisition workforce competencies survey results report. Washington, DC: Author.

Federal Acquisition Regulation, 48 C.F.R. ch. 1 (2014).

Federal Procurement Data System - Next Generation (FPDS-NG).

Fornell, C. \& Larcker, D.F. (1981). Evaluating structural equation models with unobservable variables and measurement error. Journal of Marketing Research, 18(February), 39-50.

Gates, D. (2014, December 15). "Air Force: Boeing Cost Overrun on Tanker Project Jumps to $\$ 1.5$ Billion." The Seattle Times, retrieved on January 6, 2015 at http://seattletimes.com/html/businesstechnology/2025243669 bo eingtankerxml.html. 
Gordon, D. I. (2013). Bid protests: The costs are real, but the benefits outweigh them. Public Contract Law Journal, 42(3), 489-516.

Gordon, D. I. (2011, February 2). "Myth-busting": Addressing misconceptions to improve communication with industry during the acquisition process. [Memorandum]. Washington, DC: Office of Management and Budget.

Government Accountability Office. (2014) GAO bid protest annual report to Congress for fiscal year 2013 (GAO-14-276SP). Retrieved from http://www.gao.gov/assets/660/659993.pdf

Heymann, P. B. (1987). The politics of public management. New Haven, CT: Yale University Press.

Hansen, J. M. (2009). The evolution of buyer-supplier relationships: An historical industry approach. Journal of Business \& Industrial Marketing, 24(3), 227-236.

Hair, J. F., Jr., Black, W. C., Babin, B. J., \& Anderson, R. E. (2010). Multivariate data analysis (7th ed.). Upper Saddle River, NJ: Pearson Prentice Hall.

Hawkins, T. (2012), "The U.S. Government Is Not Yet A World-Class Buyer: 15 Steps To Get There," Contract Management, (February), pp. 27-35.

Hawkins, T. and Muir, W., (2014), "An Exploration Of Knowledge-Based Factors Affecting Procurement Compliance," Journal of Public Procurement, 14(1), 1-32.

Hawkins, T., Muir, W., and Hildebrandt, G. (2011), "Determinants Of Services Sourcing Performance," Proceedings of the 8th Annual Acquisition Research Symposium, pp. 212-234.

Hoffman, I. E. (2013). "Bid Protests Get Bad Press." Public Contracting Institute, retrieved 8 June 2014 from: http://www.publiccontractinginstitute.com/bid-protests-get-badpress/.

Knauth, D. (2013, September 9). Federal contractor group calls for bid protest reforms. Retrieved from http://www.law360.com/articles/471131/federal-contractor-groupcalls-for-bid-protest-reforms

Kendall, F. (2012, November 14). Better buying power initiative 2.0 [Transcript]. Retrieved from http://csis.org/files/attachments/121114_Better_Buying_Power_tr anscript.pdf

Lam, S.Y., Shankar, V., \& Murthy, M.K.E.B. (2004). Customer value, satisfaction, loyalty, and switching costs: An illustration from a business-to-business service context. Journal of the Academy of Marketing Science, 32(3), 293-311.

Manuel, K. M., \& Schwartz, M. (2011). GAO bid protests: An overview of time frames and procedures (R40228). Retrieved from https://www.fas.org/sgp/crs/misc/R40228.pdf

Maser, S.M., Thompson, F. \& Subbotin, V. (2010). The bid protest mechanism: Effectiveness and fairness in defense acquisitions? Atkinson Graduate School of Management, Willamette University, Salem, OR 
Miller, J. (2014). "OFPP's Rung Rolls Out 3-pronged Acquisition Improvement Plan." Federal News Radio, December 4, 2014, retrieved online January 19, 2015 at http://www.federalnewsradio.com/517/3755979/OFPPs-Rungrolls-out-3-pronged-acquisition-improvement-plan .

Moore, M. H. (1995). Creating public value: Strategic management in government. Cambridge, MA: Harvard University Press.

Moore, M. H. (2000). Managing for value: organizational strategy in forprofit, nonprofit, and governmenttal organizations. Nonprofit and Voluntary Sector Quarterly, 29(1 suppl.), 183-204.

Melnyk, S. A., Page, T. J., Wu, S. J., \& Burns, L. A. (2012). Would you mind completing this survey: Assessing the state of survey research in supply chain management. Journal of Purchasing and Supply Management, 18(1), 35-45.

Nunnally, J. C. (1978). Psychometric Theory (2nd ed.), New York: McGraw-Hill.

Office of the Under Secretary of Defense for Acquisition, Technology, and Logistics. (2011). Department of Defense source selection procedures. Retrieved from http://www.acq.osd.mil/dpap/policy/policyvault/USA007183-10DPAP.pdf

O'Rourke, R. (2014). Navy littoral combat ship (LCS) program: Background and issues for congress (RL33741). Retrieved from http://www.fas.org/sgp/crs/weapons/RL33741.pdf

Pocock, C. (2009). Tanker protagonists square off for round three of U.S. bid. AIN Online, June 17, 2009, retrieved online on June 9, 2014 from: $\quad$ http://www.ainonline.com/aviation-news/paris-airshow/2009-06-17/tanker-protagonists-square-round-three-us-bid

Podsakoff, P. M., \& Organ, D. W. (1986). Self-reports in organizational research: Problems and prospects. Journal of Management, 12(4), 531-544. Retrieved from http://www.cob.unt.edu/slides/paswan/busi6280/PodsakoffOrgan \%201986.pdf

Prahinski, C., \& Benton, W. C. (2004). Supplier evaluations: Communication strategies to improve supplier performance. Journal of Operations Management, 22(1), 39-62.

Punaro, A. (2012). "Acquisition workforce strategy is the answer to DoD's problems." Federal News Radio, June 12, 2012, retrieved online June 29, 2014 at http://www.federalnewsradio.com/394/2899729/ColumnAcquisition-workforce-strategy-is-the-answer-to-DoDs-problems

Rumbaugh, M. G. (2010). Understanding government contract source selection Vienna, VA: Management Concepts.

Schwartz, M., Manuel, K. M., \& Martinez, L. P. (2009). GAO bid protests: Trends, analysis, and options for congress (R40227).

Schwartz, M., Manuel, K. M., \& Martinez, L. P. (2013). GAO bid protests: Trends and analysis (R40227). Retrieved from https://www.fas.org/sgp/crs/misc/R40227.pdf 
United States Department of Defense Inspector General (DODIG) (2009). Seaport Enhanced Program. Report Number D-2009082. Arlington, VA.

United States Merit Systems Protection Board. (2005). Contracting officer representatives: Managing the government's technical experts to achieve positive contract outcomes. Washington, DC: Author.

Young, J. (2007). Memorandum for Secretaries of the Military Departments, Chairman of the Joint Chiefs of Staff, Under Secretaries of Defense, August 24, 2007, available at https://acc.dau.mil/adl/en-

US/167825/file/30291/Competitive\%20Source\%20Selection\%20 Memo1.pdf 


\section{ACKNOWLEDGMENTS}

The authors are very appreciative of the efforts, rigor, and professionalism of three MBA students from the Naval Postgraduate School - LCDR Suquon Combs, LT Jason Calandruccio, and LT Brian Colbert. The authors also greatly appreciate the expert insights provided by Daniel I. Gordon, the Associate Dean for Government Procurement Law Studies at the George Washington University Law School and the former Administrator for the Office of Federal Procurement Policy.

Finally, we thank the three anonymous reviewers who added valuable insights. 


\section{APPENDIX A}

Interview Questions for Measurement Scale Development And Informant Demographics

\begin{tabular}{ll}
\hline & Interview question \\
\hline 1 & How important to you is avoiding a bid protest? \\
2 & Why is avoiding a bid protest important? \\
3 & What are the negative consequences of a bid protest? \\
4 & Are there any positive outcomes of receiving a bid protest? \\
5 & $\begin{array}{l}\text { Are some members of the source selection team more fixated } \\
\text { on avoiding a bid protest than others? Who? Why? } \\
\text { If there were no ability to protest, would you have done anything } \\
\text { differently in the past on a source selection (e.g., acquisition } \\
\text { strategy elements)? }\end{array}$ \\
7 & $\begin{array}{l}\text { Do you believe that source selection teams alter acquisition } \\
\text { strategies in order to avoid bid protests? What are the } \\
\text { outcomes of these alterations? } \\
\text { What extraordinary measures have you observed or heard of } \\
\text { that source selection teams have taken to avoid a bid protest? }\end{array}$ \\
\hline
\end{tabular}

Interviews

Contracting officers at two U.S. military organizations were chosen for interviews due to: (a) the convenience of travel, (b) a willingness to support the research, and (c) the availability of a wide variety of contract types and contracted goods and services for wide generalizability (e.g., external validity). A series of questions (see table above) was asked to each participant.

Eighteen individuals were interviewed over two days. Demographics of each respondent can be found in below. Each interview was recorded and transcribed. The average interview lasted 26 minutes. The interviews resulted transcribed into 229 pages. Informants were given a copy of the conceptual model during the interview and asked whether they agreed with the independent variables being used. They were also asked if they would add any or take any away. One respondent stated, "Okay. This is good. I don't see anything that I need to add." Another contracting officer stated, "I think this is a great research that you are doing because this is a bigger and bigger issue. I think you 
are right on." Other statements that validated the model were, "I think I like the model. For the most part it says everything."

\begin{tabular}{|c|c|c|c|c|c|}
\hline $\begin{array}{l}\text { Rankl } \\
\text { Grade }\end{array}$ & Gender & Duty Title & $\begin{array}{l}\text { Yrs. } \\
\text { Exp }\end{array}$ & $\begin{array}{c}\text { \# Source } \\
\text { Selections } \\
\text { (within } 2 \\
\text { yrs) }\end{array}$ & $\begin{array}{c}\text { \# Bid } \\
\text { Protest } \\
\text { (within } \\
2 \text { yrs) }\end{array}$ \\
\hline & & $\begin{array}{c}\text { Supv. } \\
\text { Contracting }\end{array}$ & & & \\
\hline GS-14 & $F$ & $\begin{array}{l}\text { Officer } \\
\text { Contracting }\end{array}$ & 29 & 12 & 0 \\
\hline GS-13 & M & $\begin{array}{c}\text { Officer } \\
\text { Contracting }\end{array}$ & 26 & 9 & 3 \\
\hline GS-13 & M & $\begin{array}{c}\text { Officer } \\
\text { Supv. } \\
\text { Contracting }\end{array}$ & 18 & 6 & 1 \\
\hline GS-14 & M & $\begin{array}{c}\text { Officer } \\
\text { Contracting }\end{array}$ & 36 & 1 & 0 \\
\hline GS-13 & $F$ & $\begin{array}{c}\text { Officer } \\
\text { Supv. } \\
\text { Contracting }\end{array}$ & 6 & 4 & 0 \\
\hline GS-14 & $F$ & $\begin{array}{l}\text { Officer } \\
\text { Contract }\end{array}$ & 32 & 3 & 0 \\
\hline GS-12 & M & $\begin{array}{l}\text { Specialist } \\
\text { Contracting }\end{array}$ & 4 & 0 & 0 \\
\hline GS-13 & M & $\begin{array}{l}\text { Officer } \\
\text { Contract }\end{array}$ & 6 & 6 & 0 \\
\hline GS-12 & M & $\begin{array}{l}\text { Specialist } \\
\text { Contracting }\end{array}$ & 7 & 4 & 2 \\
\hline GS-13 & M & $\begin{array}{c}\text { Officer } \\
\text { Contracting }\end{array}$ & 21 & 1 & 0 \\
\hline GS-13 & $F$ & $\begin{array}{c}\text { Officer } \\
\text { Contracting }\end{array}$ & 30 & 4 & 0 \\
\hline GS-13 & M & $\begin{array}{c}\text { Officer } \\
\text { Contracting }\end{array}$ & 22 & 5 & 0 \\
\hline GS-13 & $F$ & $\begin{array}{c}\text { Officer } \\
\text { Contracting }\end{array}$ & 15 & 5 & 1 \\
\hline GS-13 & M & Officer & 26 & 20 & 1 \\
\hline
\end{tabular}


APPENDIX B

Latent Construct Measurement Scales

\begin{tabular}{|c|c|c|}
\hline Label & Item & $\begin{array}{c}\text { Std. } \\
\text { Loading }\end{array}$ \\
\hline \multicolumn{3}{|c|}{ Fear of Protest } \\
\hline FEAR $^{1 *}$ & $\begin{array}{l}\text { At some point during the development } \\
\text { of the acquisition strategy or the source } \\
\text { selection process, I worried about } \\
\text { receiving a bid protest. }\end{array}$ & .82 \\
\hline FEAR $^{2 *}$ & $\begin{array}{l}\text { I was concerned that the contract award } \\
\text { would be protested. }\end{array}$ & .94 \\
\hline FEAR $^{3 *}$ & $\begin{array}{l}\text { I was anxious to get beyond the 10-day } \\
\text { point after contract award (or } \\
\text { debriefings) to determine whether or not } \\
\text { the contract would be protested. }\end{array}$ & .83 \\
\hline FEAR $^{5 * *}$ & $\begin{array}{l}\text { During the development of the } \\
\text { acquisition strategy and throughout } \\
\text { proposal evaluation, to what extent } \\
\text { were you concerned that an offeror } \\
\text { might protest the contract award? }\end{array}$ & .74 \\
\hline \multicolumn{3}{|c|}{ Perceived Contracting Officer Authority } \\
\hline $\mathrm{AUTH}^{1}$ & $\begin{array}{l}\text { I was empowered to make required } \\
\text { decisions throughout the source } \\
\text { selection. }\end{array}$ & .83 \\
\hline $\mathrm{AUTH}^{2}$ & $\begin{array}{l}\text { I was trusted that the decisions I made } \\
\text { throughout the source selection would } \\
\text { be appropriate. }\end{array}$ & .92 \\
\hline $\mathrm{AUTH}^{3}$ & $\begin{array}{l}\text { My management supported me on the } \\
\text { decisions I made during the source } \\
\text { selection. }\end{array}$ & .82 \\
\hline \multicolumn{3}{|c|}{ Sufficiency of Planned PALT } \\
\hline PALTP $^{1 *}$ & $\begin{array}{l}\text { The milestones for awarding this } \\
\text { contract were too aggressive. }\end{array}$ & .70 \\
\hline PALTP $^{2}$ & I was not rushed to award this contract. & .66 \\
\hline PALTP 3 & $\begin{array}{l}\text { I had sufficient time to get this contract } \\
\text { awarded. }\end{array}$ & .93 \\
\hline \multicolumn{3}{|c|}{ Compromised Technical Evaluation } \\
\hline CTE $^{2 *}$ & $\begin{array}{l}\text { At least one technical evaluator } \\
\text { expressed concern about not being able } \\
\text { to say what needs to be said in the } \\
\text { technical evaluation. }\end{array}$ & .84 \\
\hline CTE $^{3 *}$ & $\begin{array}{l}\text { At least one technical evaluator was } \\
\text { concerned that the constraints imposed } \\
\text { on his or her evaluations impeded the } \\
\text { evaluator's ability to write a meaningful } \\
\text { evaluation. }\end{array}$ & .91 \\
\hline CTE $^{6 *}$ & $\begin{array}{l}\text { Upon evaluation of proposals, at least } \\
\text { one technical evaluator expressed a } \\
\text { need to change at least one evaluation }\end{array}$ & .45 \\
\hline
\end{tabular}


criterion or its definition.

\section{Requirement Criticality}

$\mathrm{RC}^{2} \quad$ This requirement supported a core

competency of our customer's

organization.

$\mathrm{RC}^{3} \quad$ Compared to other purchases for this customer, this requirement was important.

$\mathrm{RC}^{4 *} \quad$ An unsuccessful outcome of the RFP would have had only minor consequences to our customer

\section{Contractor Performance}

$\begin{array}{ll}\mathrm{CP}^{1} & \text { Product/service quality per }\end{array}$

$\begin{array}{ll}\mathrm{CP}^{2} \quad \text { Delivery performance per specifications } & .92\end{array}$

$\begin{array}{lll}\mathrm{CP}^{3} & \text { Product/service consistently meets } & .92\end{array}$

$\mathrm{CP}^{5} \quad$ Required service and/or technical $\quad .89$

$\begin{array}{lll}\mathrm{CP}^{6} & \text { Non-conformance rate } & .80\end{array}$

$\begin{array}{lll}\mathrm{CP}^{7} & \text { Overall performance } & .94\end{array}$

\section{Source Selection Method Appropriateness}

$\begin{array}{lll}\text { SSMA }^{1} & \text { Our acquisition strategy was the best } & .97\end{array}$

$\begin{array}{lll}\text { SSMA }^{2} & \text { Our acquisition strategy was the best } & .94\end{array}$ means to achieve our acquisition objectives.

SSMA $^{6}$ Our acquisition strategy provided the best fit to the buying situation (e.g., complexity, dollar value, acquisition objectives, contract length, performance risk, criticality to the mission, availability of supply, time available to award a contract, etc.).

\section{Protest Risk}

$\mathrm{PR}^{1} \quad$ Increased costs to settle a terminated N/A contract(s).

$\mathrm{PR}^{2}$ Time delay to the mission. N/A

$\mathrm{PR}^{3} \quad$ Embarrassment/shame. N/A

$\mathrm{PR}^{4} \quad$ Increase in workload to resolve the N/A protest.

$\mathrm{PR}^{5} \quad$ Career repercussions for making a N/A mistake or omission that caused a bid protest.

Notes: (1) All responses were obtained using 7-point Likert-type scales;

(2) * anchors of strongly agree and strongly disagree; (3)

** anchors of not at all concerned and extremely concerned 